\title{
ANALISIS TINGKAT KEBISINGAN LALU LINTAS DI JALAN CIHAMPELAS DAN JALAN SUKAJADI KOTA BANDUNG
}

\author{
Sri Wahyuni ${ }^{*}$, Yonik Meilawati Yustiani, Andika Juliandahri \\ Program Studi Teknik Lingkungan, Universitas Pasundan
}

\begin{abstract}
Abstrak
Kebisingan dapat diartikan sebagai suara yang tidak diinginkan atau suara keras yang tidak menyenangkan atau tidak terduga. Kebisingan bersumber dari kegiatan manusia seperti penggunaan alat transportasi dan aktifitas industri. Dampak dari kebisingan ini bukan hanya pada kota-kota besar. Pengukuran tingkat kebisingan diatur dalam KEP-48/MENLH/11/1996 tentang Baku Tingkat Kebisingan. Ada dua cara yang dapat dilakukan untuk mengukur tingkat kebisingan, yaitu: cara sederhana dan cara langsung. Alat yang digunakan dalam penelitian ini yaitu sound level meter, seperangkat alat hitung dan stopwatch. Penentuan tingkat kebisingan lingkungan menggunakan sound level meter dilakukan di 2 (dua) lokasi yang merupakan daerah komersial di Kota Bandung, yaitu Jalan Cihampelas (Ciwalk) dan Jalan Sukajadi (PVJ). Berdasarkan data yang diperoleh tingkat kebisingan paling tinggi terjadi di PVJ pada saat akhir pekan yaitu sebesar 69,8 dBA. Tingkat kebisingan terendah terjadi di Ciwalk pada saat hari kerja, yaitu sebesar 68,4 dBA. Nilai ini tidak melebihi baku kebisingan berdasarkan KEPMENLH No. 48 Tahun 1996 untuk daerah perdagangan dan jasa yaitu sebesar 70 dBA.
\end{abstract}

Kata kunci: sound level meter, tingkat kebisingan, transportasi

\section{Pendahuluan}

Perkembangan perekonomian di Kota Bandung diiringi dengan berkembangnya jaringan transportasi yang pesat mengakibatkan jumlah atau volume lalu lintas terus meningkat dari waktu ke waktu, sehingga menimbulkan permasalahan-permasalahan seperti; kemacetan, polusi udara, kebisingan, kecelakaan dan lain sebagainya (Susanto, Studyana, \& Astor, 2016). Perkembangan lalu lintas akan mengakibatkan dampak positif maupun negatif yang selanjutnya akan dirasakan langsung oleh masyarakat (Mulyatna, Rusmaya, \& Baehakhi, 2017). Salah satu dampak negatif dari arus lalu lintas yang

\footnotetext{
${ }^{*}$ Penulis Korespondensi:

E-mail: sriwahyunisugandi@yahoo.com

Diterima pertama kali: 13 Desember 2017

Direvisi : 5 Februari 2018

Disetujui untuk publikasi: 7 Februari 2018
}

semakin padat ialah kebisingan yang ditimbulkan oleh kendaraan (Mulyono, 2012).

Kebisingan lalu lintas berasal dari suara yang dihasilkan kendaraan bermotor, terutama mesin kendaraan, knalpot, serta akibat interaksi antara roda dengan jalan (Ouis, 2001). Kendaraan bermotor merupakan sumber kebisingan utama di jalan raya. Jalan Cihampelas merupakan jalan yang saat ini tingkat kepadatan volume lalu lintasnya sangat tinggi apalagi disaat akhir pekan sehingga terdapat peluang untuk menimbulkan kebisingan yang tinggi pula.

Dalam UU No.22 tahun 2009 pasal 209 disebutkan bahwa setiap kegiatan di bidang lalu lintas dan angkutan jalan harus dilakukan pencegahan dan penanggulangan pencemaran lingkungan hidup untuk memenuhi keputusan baku mutu lingkungan yang telah disyaratkan. 
Hal ini dimaksudkan untuk mengurangi dampak negatif terhadap lingkungan.

Jalan Cihampelas Kota Bandung. Daerah perdagangan dan jasa memiliki ambang batas kebisingan yang telah disyaratkan oleh menteri lingkungan hidup yaitu maksimal sebesar 70 dBA (Kep.Ment. LH 48 tahun 1996), oleh sebab itu perlu adanya penelitian untuk menganalisa tingkat kebisingan pada ruas jalan teresebut agar dapat diambil solusi yang mungkin dilakukan guna mengurangi kebisingan sehingga tidak melebihi batas yang telah disyaratkan.

Tujuan penelitian ini adalah untuk mengetahui tingkat kebisingan yang terjadi di Jalan Cihampelas Kota Bandung, apakah masih sesuai dengan baku mutu atau tidak (Kep.Ment. LH 48 tahun 1996).

\section{Metodologi}

Metodologi yang digunakan dalam pelaksanaan penelitian ini adalah seperti yang telihat pada Gambar 1.

Data yang diambil dari pengukuran langsung di lapangan. Pengambilan data menggunakan metode pengukuran kebisingan yang terncatum dalam lampiran II KEP No.48/MENLH/11/1996 tentang baku mutu tingkat kebisingan.

Berikut ini merupakan metode pengukuran kebisingan secara langsung :

- SLM dipasang dalam daerah rawan bising yaitu 10 meter dari tepi perkerasan dengan ketinggian 1,2 - 1,5 meter.

- Survei dilaksanakan di dualokasi, yaituJalan Cihampelas (Ciwalk) danJalan Sukajadi (PVJ).

- Pengukuran pada siang hari antara jam 09.00 sampai dengan jam 20.00 wib.

- SLM dipajang selama 10 menit dengan pembacaan tiap 5 detik.

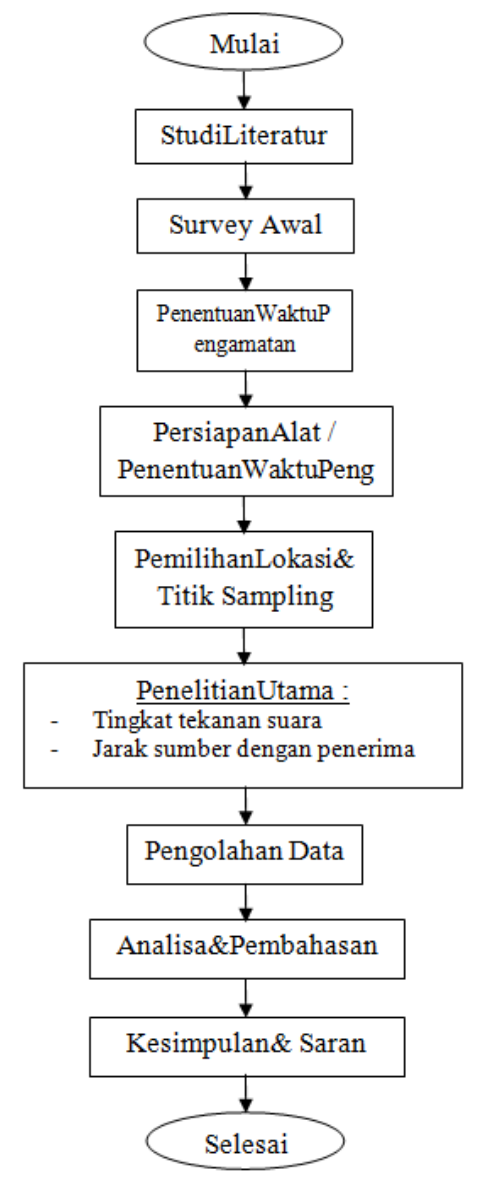

Gambar 1. Metode pengukuran sampel.

\section{Hasil dan Pembahasan}

Pemeriksaan kebisingan di Jalan Cihampelas (Ciwalk) dapat dilihat pada Tabel 1.

Tabel 1 Leq 10 menit di Jalan Cihampelas (Ciwalk)

\begin{tabular}{ccc}
\hline Jam & Mewakili & $\begin{array}{c}\text { Leq 10 menit } \\
(\mathbf{d b A})\end{array}$ \\
\hline 9.00 & $06.00-10.00$ & 68,4 \\
\hline 12.00 & $10.00-13.00$ & 70,6 \\
\hline 16.00 & $13.00-17.00$ & 69,3 \\
\hline 20.00 & $17.00-22.00$ & 68,9 \\
\hline
\end{tabular}

Berdasarkan Tabel 1, nilai tingkat kebisingan tertinggi di Ciwalk adalah pada jam 12.00 WIB, hal ini dapat disebabkan karena pada jam 
tersebut bertepatan dengan jam istirahat kantor, banyak kendaraan yang masuk ke Ciwalk.

Tabel 2. Leq 10 menit di Jalan Sukajadi (PVJ)

\begin{tabular}{ccc}
\hline Jam & Mewakili & Leq 10 menit (dbA) \\
\hline 9.00 & $06.00-10.00$ & 70 \\
\hline 12.00 & $10.00-13.00$ & 67,5 \\
\hline 16.00 & $13.00-17.00$ & 70,9 \\
\hline 20.00 & $17.00-22.00$ & 69,9 \\
\hline
\end{tabular}

Berdasarkan Tabel 2 nilai tingkat kebisingan tertinggi di PVJ adalah pada jam 16.00 WIB, hal ini dapat disebabkan karena pada jam tersebut bertepatan dengan jam pulang kantor, banyaknya antrian kendaraan yang memasuki PVJ menyebabkan kemacetan di JalanSukajadi.

Tabel 3. Leq 10 menit di 2 Lokasi Pengukuran pada saat hari kerja

\begin{tabular}{cccc}
\hline Jam & Mewakili & Ciwalk & PVJ \\
\hline 9:00 & $06.00-10.00$ & 68,4 & 70,0 \\
\hline 12:00 & $10.00-13.00$ & 70,6 & 67,5 \\
\hline 16:00 & $13.00-17.00$ & 69,3 & $\mathbf{7 0 , 9}$ \\
\hline 20:00 & $17.00-22.00$ & 68,9 & 69,9 \\
\hline
\end{tabular}

Berdasarkan Tabel 3 kebisingan tertinggi terjadi di PVJ pada pukul 19.00 WIB hal ini disebabkan karena pada jam tesebut bertepatan dengan jam pulang kantor, banyak kendaraan masuk ke area pusat perbelanjaan PVJ sehingga menyebakan tingginya tingkat kebisingan.

Tabel4 Leq 10 menit di 2 Lokasi Pengukuran pada saat akhir pekan

\begin{tabular}{cccc}
\hline Jam & Mewakili & Ciwalk & PVJ \\
\hline 9:00 & $06.00-10.00$ & 66,8 & 66,9 \\
\hline 12:00 & $10.00-13.00$ & 65,7 & 65,8 \\
\hline 16:00 & $13.00-17.00$ & $\mathbf{7 0 , 1}$ & 70,0 \\
\hline 20:00 & $17.00-22.00$ & 69,2 & 69,1 \\
\hline
\end{tabular}

Berdasarkan Tabel 4 tingkat kebisingan tertinggi pada saat akhir pekan terjadi di Ciwalk pada pukul 16.00 WIB hal ini dikarenakan tingginya arus kendaraan yang melewati dan masuk ke Ciwalk, terutama kendaraan dari luar Kota Bandung yang ingin berbelanja di sekitar Jalan Cihampelas yang memang dipenuhi oleh pedagang kaki lima maupun took pakaian.

Gambar 2 adalah grafik perbandingan tingkat kebisingan (Leq 10 menit) di 2 lokasi pengukuran.

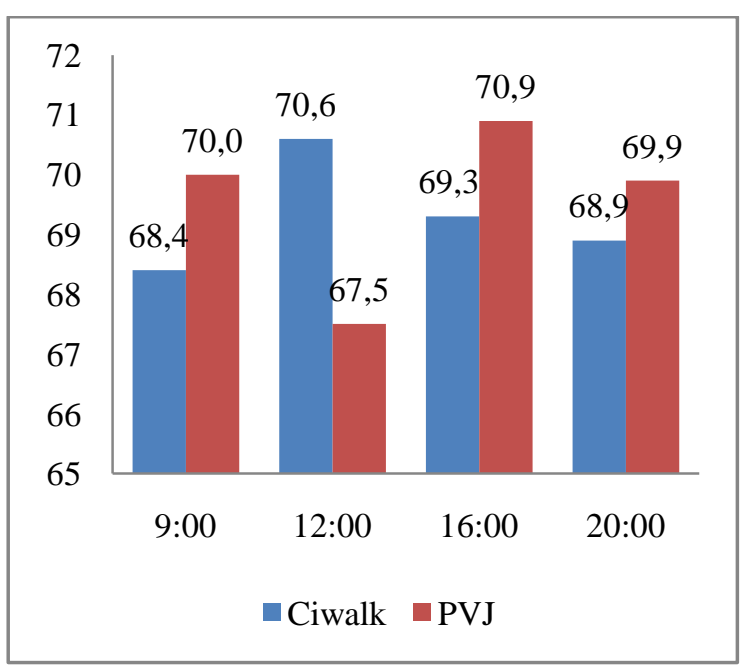

Gambar 2 Grafik Leq 10 menit berdasarkan waktu pengukuran pada saat hari kerja

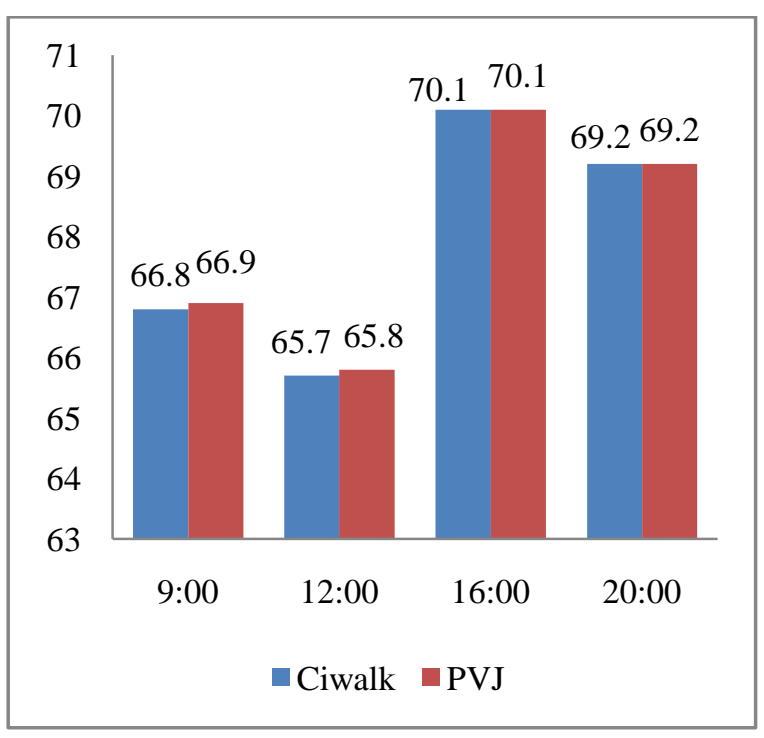

Gambar 3 Grafik Leq 10 menit berdasarkan waktu Pengukuran pada saat akhir pekan

Setelah diketahui Leq 1 menit dan Leq 10 menit maka selanjutnya dapat diketahui Intensitas Kebisingan Siang hari (Ls) pada saat hari kerja, 
untuk lebih jelasnya dapat dilihat pada contoh perhitungan berikut ini :

$$
\begin{aligned}
\mathrm{L}_{\mathrm{S}}= & 10 \log \frac{1}{16}\left(\mathrm{~T}_{\mathrm{a}} 10^{0,1 \mathrm{~L}_{\mathrm{a}}}+\ldots+\mathrm{T}_{\mathrm{d}} 10^{0,1 \mathrm{~L}_{\mathrm{d}}}\right) \\
= & 10 \log \frac{1}{16}\left(4 \times 10^{0,1(68,4)}+3 \times 10^{0,1(70,6)}\right. \\
& \left.\quad+4 \times 10^{0,1(69,3)}+5 \times 10^{0,1(68,9)}\right) \\
= & 69.24 \mathrm{dBA}
\end{aligned}
$$

Tabel 5 Tingkat Kebisingan Siang Hari (Ls) Total

\begin{tabular}{cccc}
\hline Lokasi & $\begin{array}{c}\text { AkhirPe } \\
\text { kan } \\
\text { (dBA) }\end{array}$ & $\begin{array}{c}\text { HariKerja } \\
\text { (dBA) }\end{array}$ & $\begin{array}{c}\text { Baku } \\
\text { Mutu } \\
\text { (dBA) }\end{array}$ \\
\hline Ciwalk & $\mathbf{6 9 , . 2}$ & 68,4 & 70 \\
\hline PVJ & $\mathbf{6 9 , 8}$ & 68,5 & 70 \\
\hline
\end{tabular}

Berdasarkan Tabel 5 dari 2 lokasi titik sampling hasil perhitungan tingkat kebisingan siang hari yang diperoleh, nilainya tidak melebihi baku mutu untuk kebisingan berdasarkan Keputusan Menteri Negara Lingkungan Hidup No. 48 Tahun 1996 tentang Baku Tingkat Kebisingan untuk wilayah perdagangan dan jasa yaitu sebesar $70 \mathrm{dBA}$.

Perbandingan kebisingan saat hari kerja dan akhir pekan tidak menunjukkan perbedaan yang berarti. Hal ini disebabkan kepadatan transportasi yang tidak jauh berbeda antara kedua situasi tersebut. Hal ini juga ditunjukkan pada lokasi lain yang memiliki karakteristik yang mirip (Geraghty \& O'Mahony, 2016).

\section{Kesimpulan}

Hasil pengukuran tingkat kebisingan siang hari (Ls) di 4 (empat) lokasi pengukuran yang mewakili daerah perdagangan dan jasa Kota Bandung, yaitu Jalan Cihampelas, Jalan Sukajadi, Jalan R.E Martadinata dan Jalan Ir. H. Juanda paling tinggi terjadi pada saat weekend di PVJ (Jalan Sukajadi) yaitu sebesar 69.8 dBA. Dengannilai ini dapat disimpulkan bahwa tingkat kebisingan tidak melebihi baku mutu berdasarkan KEPMEN LH No.48 Tahun 1996 tentang baku tingkat kebisingan untuk wilayah perdagangan dan jasa yaitu sebesar $70 \mathrm{dBA}$.

\section{Daftar Pustaka}

Geraghty, D., \& O'Mahony, M. (2016). Investigating the temporal variability of noise in an urban environment. International Journal of Sustainable Built Environment, Vol. 5, Issue 1: 34-45.

Mulyatna, L., Rusmaya, D., \& Baehakhi, D. (2017). Hubungan Kebisingan dengan Persepsi Masyarakat di Ruang Rawat Inap Rumah Sakit Kelas A, Kelas B, dan Kelas B Kota Bandung. Journal of Community Based Environmental Engineering and Management, Vol. 1, No. 1: 25-31.

Mulyono, G. S. (2012). Analisis Kebisingan Akibat Arus Lalulintas di Rumah Sakit PKU Muhammadiyah Surakarta. Seminar Nasional Teknik Sipil UMS 2012, 65-70.

Ouis, D. (2001). Annoyance from Road Traffic Noise: A Review. Journal of Environmental Psychology, Vol 21, Issue 1: 101-120. 